\title{
Vitamin D deficiency and insufficiency in patients with chronic kidney disease
}

\author{
Insuficiência e deficiência de vitamina D em pacientes portadores \\ de doença renal crônica
}

\begin{abstract}
Authors
Herculano Ferreira Diniz ${ }^{1}$ Mariana Fadil Romão ${ }^{1}$ Rosilene Motta Elias ${ }^{1}$ João Egídio Romão Júnior ${ }^{1}$
\end{abstract}

${ }^{1}$ Nefrology Service at Hospital das Clínicas at the Medical School of Universidade de São Paulo - FMUSP.

Submitted on: 09/30/2011 Approved on: 11/16/2011

Correspondence to: João Egídio Romão Junior Rua Maestro Cardim 560, conjunto 172 ,

São Paulo - SP - Brazil

Zip code 01323-000

E-mail: joaoegidio@hcnet. usp.br

This study was undertaken at Hospital das Clínicas at the Medical School of Universidade de São Paulo - FMUSP.

The authors report no conflict of interest.

\section{Abstract}

Introduction: Vitamin D deficiency is common among patients with chronic kidney disease (CKD). A higher level of serum vitamin $\mathrm{D}$ is expected in residents of the tropics in relation to inhabitants of non-tropical regions, due to greater sun exposure and increased production of vitamin D. Objective: To analyze serum levels of vitamin $\mathrm{D}$, such as 25-hydroxyvitamin D - 25(OH)D, in Brazilian patients at the predialytic stage with CKD. Methods: We studied 125 patients (aged $57.4 \pm 16.2$ years, 78 were white and $55.2 \%$, male), with creatinine $2.67 \pm 1.73 \mathrm{mg} / \mathrm{dL}$ and creatinine clearance $43.7 \pm 34.5 \mathrm{~mL} / \mathrm{min}$. Body mass index was $27.4 \pm 4.7 \mathrm{~kg} / \mathrm{m}^{2}$, and waist circumference was $95.0 \pm 14.0 \mathrm{~cm}$. Calcium was $9.3 \pm 0.6 \mathrm{mg} / \mathrm{dL}$, intact parathormone (iPTH) $212.6 \pm 221.2 \mathrm{pg} / \mathrm{mL}$ and serum albumin $4.2 \pm 0.6 \mathrm{~g} / \mathrm{dL}$. The mean $25(\mathrm{OH})$ D was $23.9 \pm 10.7 \mathrm{ng} / \mathrm{mL}$. Results: Out of the 125 patients, we found that $92(72.6 \%)$ had suboptimal levels of $25(\mathrm{OH}) \mathrm{D}<30 \mathrm{ng} / \mathrm{mL}$, and $65(52 \%)$ had vitamin D insufficiency $(15-29 \mathrm{ng} / \mathrm{mL}) ; 27$ $(21.5 \%)$ had deficiency $(5-14 \mathrm{ng} / \mathrm{mL})$ and only one patient had severe vitamin $\mathrm{D}$ deficiency $<5 \mathrm{ng} / \mathrm{mL}$. No differences were observed among the levels of 25 $(\mathrm{H}) \mathrm{D}$ in stratified patients as to the CKD stage. Levels of $25(\mathrm{OH}) \mathrm{D}$ were higher among males $(38.1 \pm 20.6$ versus $22.4 \pm$ $9.7 \mathrm{ng} / \mathrm{mL} ; \mathrm{p}<0.0001)$, and there was an inverse correlation between levels $25(\mathrm{OH}) \mathrm{D}$ and $\mathrm{iPTH}$, proteinuria and abdominal circumference, and a positive correlation between $25(\mathrm{OH}) \mathrm{D}$ and calcium and serum albumin. Multivariate analysis only showed inverse correlation between serum 25(OH)D and iPTH and abdominal circumference. Conclusion:

\section{Resumo}

Introdução: Hipovitaminose $\mathrm{D}$ é bem documentada em pacientes portadores de doença renal crônica (DRC). Espera-se níveis inferiores em habitantes de regiões não tropicais em relação aos habitantes de regiões tropicais, pela inferição de uma maior exposição solar e maior produção de vitamina D. Objetivo: Analisar os níveis séricos de vitamina $\mathrm{D}$, como 25 -hidroxivitamina $\mathrm{D}-25(\mathrm{OH}) \mathrm{D}$, de 125 pacientes brasileiros portadores de DRC em fase pré-dialítica. Métodos: Foram estudados 125 pacientes $(57,4 \pm 16,2$ anos, 78 brancos e $55,2 \%$ homens), com creatinina de $2,67 \pm 1,73 \mathrm{mg} / \mathrm{dL}$ e o clearance estimado $43,7 \pm 34,5 \mathrm{~mL} / \mathrm{min}$. O índice de massa corporal era de $27,4 \pm 4,7 \mathrm{~kg} / \mathrm{m}^{2}$ e a circunferência abdominal de 95,0 $\pm 14,0 \mathrm{~cm}$. O cálcio era de 9,3 $\pm 0,6 \mathrm{mg} / \mathrm{dL}$, o paratormônio intacto (PTHi) 212,6 $\pm 221,2$ $\mathrm{pg} / \mathrm{mL}$ e a albumina sérica $4,2 \pm 0,6 \mathrm{~g} / \mathrm{dL}$. A média de $25(\mathrm{OH}) \mathrm{D}$ era de $23,9 \pm 10,7$ ng/mL. Resultados: Dos 125 pacientes, 92 $(72,6 \%)$ apresentavam níveis de $25(\mathrm{OH})$ $\mathrm{D}<30 \mathrm{ng} / \mathrm{mL}$, sendo que $65(52 \%)$ apresentavam insuficiência $(15-29 \mathrm{ng} / \mathrm{mL}) ; 27$ $(21,5 \%)$ apresentavam deficiência (5-14 $\mathrm{ng} / \mathrm{mL}$ ) e apenas um paciente apresentava deficiência severa $<5 \mathrm{ng} / \mathrm{mL}$. Não foram observadas diferenças entre os níveis de $25(\mathrm{OH}) \mathrm{D}$ nos pacientes estratificados quanto ao estágio de DRC. Os níveis de $25(\mathrm{OH}) \mathrm{D}$ foram maiores nos homens $(38,1 \pm 20,6$ versus $22,4 \pm 9,7 \mathrm{ng} / \mathrm{mL}$; $\mathrm{p}<0,0001)$, havendo também uma correlação inversa entre os níveis de $25(\mathrm{OH})$ $\mathrm{D}$ e de PTHi, proteinúria e circunferência abdominal, e uma correlação positiva entre $25(\mathrm{OH}) \mathrm{D}$ e cálcio total e albumina sérica. $\mathrm{Na}$ análise multivariada, encontrou-se apenas correlação inversa entre $25(\mathrm{OH}) \mathrm{D}$ e circunferência abdominal e 
Even though the Brazilian population live in a tropical region, most patients had suboptimal levels of serum vitamin $\mathrm{D}$, and this pattern may play a role in the development of hyperparathyroidism.

Keywords: Vitamin D. Vitamin D deficiency. Renal insufficiency, chronic. Nutrition assessment.
PTHi. Conclusão: A despeito de a população do Brasil estar em um clima tropical, a maioria dos pacientes analisados apresentou níveis séricos subótimos de vitamina $\mathrm{D}$, podendo este achado estar relacionado ao desenvolvimento de hiperparatireoidismo.

Palavras-chave: Vitamina D. Deficiência de vitamina D. Insuficiência renal crônica. Avaliação nutricional.

\section{INTRODUCTION}

Chronic kidney disease (CKD) is identified as a risk factor for vitamin D deficiency, and many papers show that the frequency of deficiency is high among these patients. ${ }^{1-7}$ Even though little attention has been given to this association up until recently, ${ }^{8,9}$ vitamin $\mathrm{D}$ deficiency is not only associated with the increased risk of osteometabolic disease, but also to other relevant clinical issues, including different types of neoplasms, ${ }^{3-5}$ besides the risk of cardiovascular diseases. ${ }^{10}$ At the same time, low levels of vitamin $\mathrm{D}$ have been associated with the high mortality rates in the general population and in patients who undergo hemodialysis (HD). ${ }^{11}$

The serum concentration of 25-hydroxyvitamin $\mathrm{D}-25(\mathrm{OH}) \mathrm{D}$ is the main circulating form of vitamin $\mathrm{D}$, used to determine the body standard of vitamin D. It is little studied in regions where solar radiation is considered sufficient, and little is known about the magnitude of vitamin D deficiency in Brazil, be it in the general population or among those who have CKD. ${ }^{12,13}$ Even if Brazil is considered to be an adequate country concerning exposure to the sun, a high percentage of vitamin D deficiency has been reported among people who live in São Paulo. ${ }^{13}$

The objective of this study was to study the frequency of vitamin D deficiency among patients who have CKD undergoing conservative non-dyalitic treatment, followed-up at a university reference center.

\section{SAMPLE AND METHODS}

Serum levels of $25(\mathrm{OH}) \mathrm{D}$ were analyzed in $25 \mathrm{pa}$ tients who have pre-dialytic CKD; they were aged more than 18 years, being clinically stable and followed-up at the uremia outpatient clinic from 20082009. A cross-sectional analysis of serum levels of $25(\mathrm{OH}) \mathrm{D}$ and the correlation with anthropometrical (height, weight, abdominal circumference and waist) and lab data [creatinine, alkaline phosphatase, gamma-glutamyltransferase (gamma-GT), total and ionic calcium, phosphorus, albumin, intact parathormone (iPTH) and proteinuria] were performed.
CKD was defined as the estimated creatinine clearance $(\mathrm{CrC})<90 \mathrm{~mL} / \mathrm{min}$ and signs of renal lesion. ${ }^{14,15}$ Patients were stratified in four stages of CKD, according to the guidelines of the Brazilian Society of Nephrology: $:^{15}$ stage 2 - slight or functional CKD (CrC from $60-89 \mathrm{~mL} / \mathrm{min}$ ); stage 3 - moderate or lab CKD (CrC from 30-59 $\mathrm{mL} / \mathrm{min}$ ); stage 4 - severe or clinical CKD (CrC from $15-29 \mathrm{~mL} / \mathrm{min}$ ); and stage 5 - pre-dialytic CKD $(\mathrm{CrC}<15 \mathrm{~mL} / \mathrm{min})$.

None of the patients was on vitamin $\mathrm{D}$ supplementation, and the confirmed diagnosis of CKD was the only indication for the dosage of serum $25(\mathrm{OH})$ $\mathrm{D}$; the patient should also be included in a research protocol previously approved by the Research Ethics Committee of the institution.

Blood samples were drawn for lab tests after an eight-hour fast, and included the blood dosage of: creatinine, urea, calcium - reference value $(\mathrm{RV})(=8.5$ to $10.5 \mathrm{mg} / \mathrm{dL}$ ), phosphorus ( $\mathrm{RV}=2.3$ to $4.6 \mathrm{mg} / \mathrm{dL}$ ), alkaline phosphatase ( $\mathrm{RV}=40$ to $104 \mathrm{U} / \mathrm{L})$, bicarbonate, albumin and $\mathrm{PTH}(\mathrm{RF}=11$ to $62 \mathrm{pg} / \mathrm{mL}$ ). Biochemical dosages were performed by the automated method (Autoanalyzer, EUA). Serum iPTH was measured by the immunoradiometric methods (IRMA). Serum creatinine was measured by the automated method, by Jaffe reaction, and the renal function was evaluated by creatinine clearance $(\mathrm{CrC}$; in $\mathrm{mL} / \mathrm{min})$ estimated by the Cockcroft-Gault equation: ${ }^{16}\{\mathrm{CrC}=$ [(140-age) $\mathrm{x}$ weight $] /(72 \mathrm{x} \mathrm{Cr})\}$, multiplied by 0.85 for women, since age is measured in years; weight, in kilograms; and serum creatinine $(\mathrm{Cr})$, in $\mathrm{mg} / \mathrm{dL}$. Total serum calcium was corrected by the concentration of serum albumin with the equation: ${ }^{17} \mathrm{Cac}=\mathrm{Ca}+$ $[0.8 \times(4.5-\mathrm{Alb})]$. All dosages were performed at the Central Laboratory of the Hospital. The dosage of serum concentration of $25(\mathrm{OH}) \mathrm{D}$ was performed by the Diasorin Liaisontm method (USA), based on chemiluminescence to recognize vitamin D-binding proteins. Vitamin D deficiency and insufficiency were defined according to the guidelines proposed by the Kidney Disease: Improving Global Outcomes (KDIGO). ${ }^{18}$ Thus, serum levels of vitamin D were considered as adequate when the concentration of $25(\mathrm{OH}) \mathrm{D}$ was 
higher than $30 \mathrm{ng} / \mathrm{mL}$; levels between 16-30 ng/mL were considered as insufficient, and values that were equal or lower than $15 \mathrm{ng} / \mathrm{mL}$ defined the diagnosis of vitamin D deficiency.

\section{STATISTICAL ANALYSIS}

Characteristics of patients were summarized by frequency, for categorical variables, and by central tendency for continuous variables (mean \pm standard deviation). Continuous variables were tested as to normal distribution with the Kolmogorov-Smirnov test, and the differences were analyzed by the MannWhitney test. In order to analyze CKD stages, the one-way (ANOVA) technique was used. Meanwhile, the linear correlation analysis was used to determine the relations between continuous variables (Pearson's or Spearman's coefficient, when indicated). The univariate analysis was used to correlate serum levels of $25(\mathrm{OH}) \mathrm{D}$ and the clinical and biochemical parameters studied with the multiple linear regression analysis (stepwise) to check for independent predictors of the concentration of $25(\mathrm{OH}) \mathrm{D}$. Variables that presented significant correlations in the univariate analysis were included in the model. Differences with $p<0.05$ were considered significant. The software SPSS for Windows (Inc., Chicago, III, USA) was used for analysis.

\section{Results}

\section{Basal CHARACTERISTICS OF THE PATIENTS}

The characteristics of the studied patients are demonstrated in Table 1 . Out of the 125 analyzed patients, $69(55.2 \%)$ were males, with mean age of $57.4 \pm 16.2$ years (ranging from 18-85 years). Seventy eight were white. The most common primary renal disease was hypertensive nephroangiosclerosis (in 45 patients) and diabetic nephropathy (in 32 patients). No patient presented with severe liver injury, congestive heart failure or malignant neoplasm. Mean weight of the patients was $72.1 \pm 15.8 \mathrm{~kg}$, body mass index (BMI) was $27.4 \pm 4.7 \mathrm{~kg} / \mathrm{m}^{2}$ (variation: $17.4-42.4 \mathrm{~kg} / \mathrm{m}^{2}$ ), mean waist was $95.0 \pm 14.1 \mathrm{~cm}$. The analyzed biochemical variables are also demonstrated in Table 1. Serum creatinine was $2.66 \pm 1.74 \mathrm{mg} / \mathrm{dL}$, and the estimated creatinine clearance was $43.7 \pm 34.5 \mathrm{~mL} / \mathrm{min}$ (variation: $8.7-89.3 \mathrm{~mL} / \mathrm{min}$ ).

\section{VITAMIN D STANDARD AMONG PATIENTS}

Out of the 125 analyzed patients, 92 (73.6\%) had low levels of serum $25(\mathrm{OH})$, that is, serum concentration was $\leq 30 \mathrm{ng} / \mathrm{mL}$; out of these, $65(52.0 \%)$ had

\begin{tabular}{lc} 
Table 1 & $\begin{array}{c}\text { ClinICAL AND LABORATORY DATA OF THE } \\
\text { 125 STUDIED PATIENTS }\end{array}$ \\
Patients & 125 \\
\hline Age (years) & $57.4 \pm 16.3$ \\
Males & $69(55 \%)$ \\
Weight $(\mathrm{kg})$ & $72.1 \pm 15.8$ \\
BMI $\left(\mathrm{kg} / \mathrm{m}^{2}\right)$ & $27.4 \pm 4.7$ \\
Waist $(\mathrm{cm})$ & $95 \pm 14$ \\
Hip (cm) & $103 \pm 11$ \\
Waist/hip index & $0.92 \pm 0.09$ \\
Men & $0.97 \pm 0.06$ \\
Women & $0.87 \pm 0.09$ \\
Creatinine clearance (mL/min) & $43.7 \pm 34.5$ \\
Creatinine (mg/dL) & $2.66 \pm 1.74$ \\
Calcium (mg/dL) & $9.3 \pm 0.6$ \\
lonic calcium (mg/dL) & $5.1 \pm 0.4$ \\
Phosphorus (mg/dL) & $3.9 \pm 0.8$ \\
iPTH & $212.6 \pm 221.2$ \\
Alkaline phosphatase (UI) & $94.1 \pm 34.6$ \\
Gamma-glutamyltransferase & $52.0 \pm 66.2$ \\
Albumin & $4.2 \pm 0.6$ \\
24h proteinuria & $1.12 \pm 2.27$ \\
\hline
\end{tabular}

BMI: body mass index; iPTH: intact parathormone.

Figure 1. Values of 25(OH)D in relation to the renal function, stratified according to CKD staging (ANOVA: $\mathrm{p}=0.1258$ ).

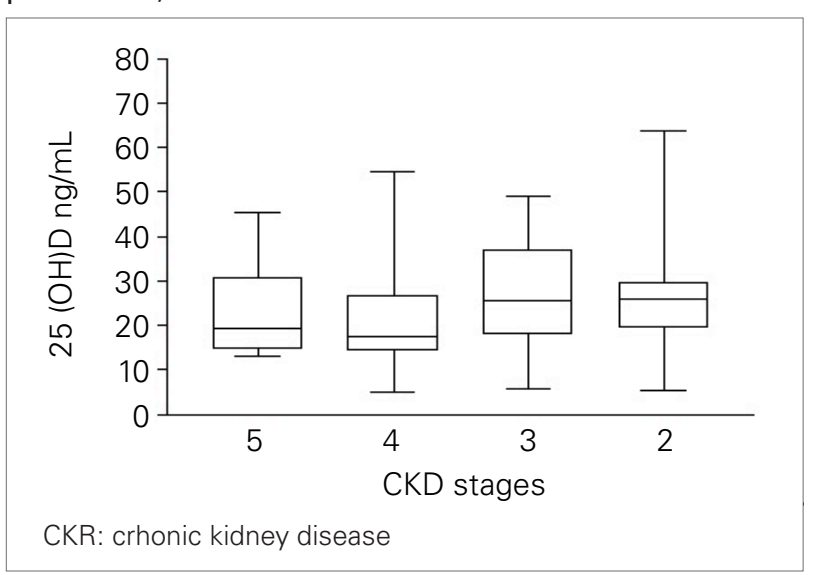

insufficient levels of vitamin $\mathrm{D}$, and the 27 others $(21.6 \%)$ had levels lower than $15 \mathrm{ng} / \mathrm{mL}$, considered as deficient. Only one patient presented less than $5 \mathrm{ng} /$ $\mathrm{mL}$, which is considered as severe insufficiency. No differences were observed between levels of $25(\mathrm{OH})$ $\mathrm{D}$ in patients stratified as to CKD stage ( $\mathrm{p}=0.1258)$ - Figure 1. In the univariate analysis, no correlation between serum levels of $25(\mathrm{OH}) \mathrm{D}$ and the estimated creatinine clearance of patients $(\mathrm{r}=0.03346 ; \mathrm{p}=$ 0.7122) was observed - Figure 2. Likewise, the age, height, weight, ionic calcium, phosphorus, creatinine, 
alkaline phosphatase and gamma-GT of the patients were not correlated. Serum levels of $25(\mathrm{OH}) \mathrm{D}$ were higher for males $(38.1 \pm 20.6 \mathrm{ng} / \mathrm{mL}$ versus $22.4 \pm$ $9.7 \mathrm{ng} / \mathrm{mL} ; \mathrm{t}=5.377, \mathrm{p}<0.0001$ ).

Serum concentrations of iPTH ranged from 23$1.076 \mathrm{pg} / \mathrm{mL}$, and a significant negative correlation was noticed between $25(\mathrm{OH}) \mathrm{D}$ and serum iPHT $(\mathrm{r}=-0.317, \mathrm{p}=0.013)-$ Figure 3, the waist circumference of patients $(\mathrm{r}=-0,189, \mathrm{p}=0.045)$ and 24 hour proteinuria $(r=-0.315, p=0.0063)$. Levels of $25(\mathrm{OH}) \mathrm{D}$ were also significantly correlated with the concentrations of total serum calcium $(\mathrm{r}=-.2110$, $\mathrm{p}=0.04)$ and serum albumin $(\mathrm{r}=0.2601, \mathrm{p}=0.03)$. At the multivariate analysis, independent predictors of levels of $25(\mathrm{OH}) \mathrm{D}$ were waist circumference $[$ coefficient $=-0.1515$, standard error $(\mathrm{SE})$ $=0.07566 \mathrm{~m}, \mathrm{r}=-2.002, \mathrm{p}=0.0332]$ and $\mathrm{iPTH}$ con centrations $($ coefficient $=-0.01168, \mathrm{SE}=0.004551$, $\mathrm{r}=-2.567, \mathrm{p}=0.0063)$.

Figure 2. Values of $25(\mathrm{OH}) \mathrm{D}$ in relation to the renal function: (A) normal levels; (B) insufficient levels and (C), levels of vitamin $D$ deficiency $(r=0.048 ; p=0.6017)$.

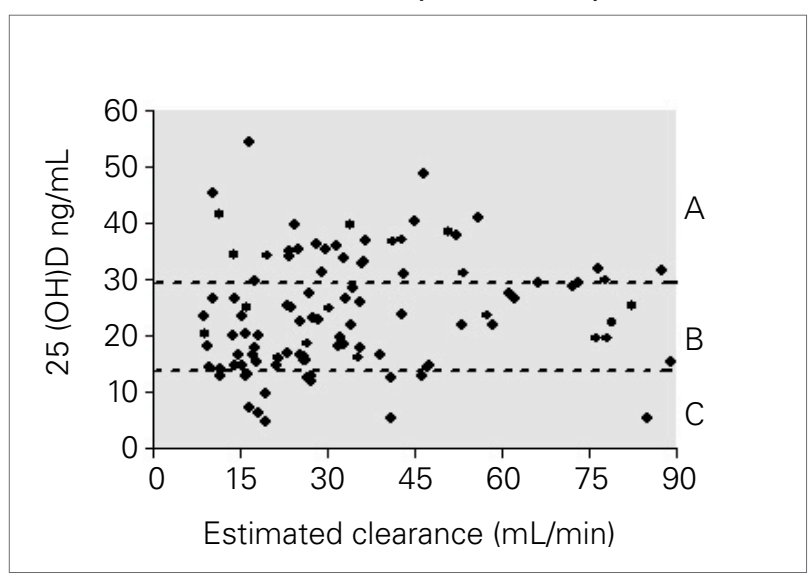

Figure 3. Correlation between serum levels of $25(\mathrm{OH})$ $D$ and serum concentrations of $\mathrm{iPTH}$ of the studied patients $(r=-0.3179 ; p=0.0130)$.

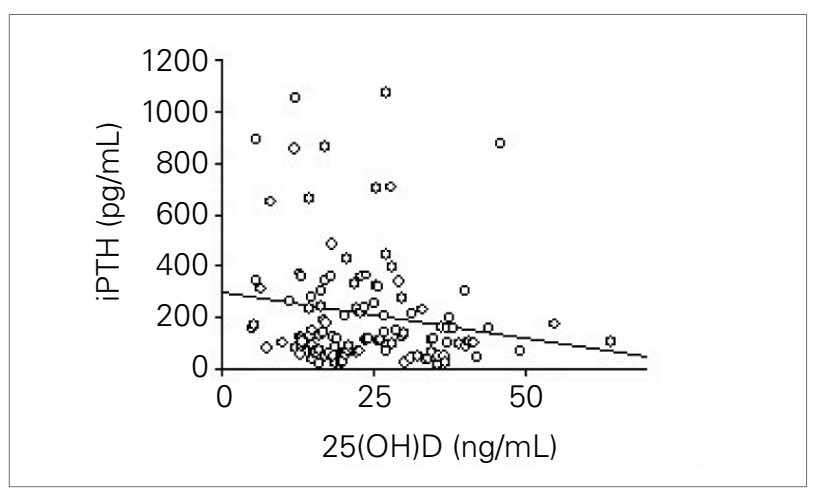

\section{Discussion}

This study showed a high prevalence of vitamin D deficiency/insufficiency in patients with pre-dialytic $\mathrm{CKD}$, and this condition is observed in $72.6 \%$ of the studied patients. Besides, low values of $25(\mathrm{OH})$ $\mathrm{D}$ were associated with high levels of iPHT and abdominal circumference of patients. These data suggest an important role of the suboptimal levels of vitamin $\mathrm{D}$ in the physiopathogeny of hyperparathyroidism in patients with CKD.

The presence of vitamin D deficiency in the general population and in patients with CKD has been described. It is estimated that about 1 million people all over the world have vitamin D deficiency ${ }^{11}$, and the extensive 2007 North-American study, NHANES, showed a significant deficiency of $25(\mathrm{OH}) \mathrm{D} 3$ in patients with stage 4 CKD. ${ }^{19}$ Concerning those who do not have CKD, data on blood levels of vitamin D are scarce, being almost exclusively described in small groups of individuals such as children, adolescents and the elderly.

This clinical problem has always been seen as something small in our country, since most of its territory is located in a tropical region, where the incidence of sun light is excessive. However, such premise has been refuted by studies that prove the high frequency of vitamin D deficiency in the Brazilian population ${ }^{13,20-22}$. A study that included 250 elderly people living in São Paulo demonstrated a high and unexpected prevalence of vitamin $\mathrm{D}$ deficiency $(15.4 \%)$ and insufficiency $(41.9 \%) .{ }^{21}$ Also in relation to Brazilian data, a study was performed with 16 healthy teenagers from the countryside of São Paulo and showed high prevalence $(60 \%)$ of vitamin D insufficiency. ${ }^{22}$ A study involving 603 normal volunteers, also from São Paulo, found mean value of $25(\mathrm{OH}) \mathrm{D}$ of $21.4 \mathrm{ng} / \mathrm{mL}$, and $77.4 \%$ of the analyzed patients had vitamin D deficiency. ${ }^{13}$ Vitamin D deficiency was more common among black people and the elderly population; it was associated to higher blood levels of PTH and was more common during the winter.

In relation to patients with non-dialytic CKD, data in this study showed the high prevalence of vitamin D deficiency and insufficiency, according to literature. ${ }^{1,2}$ Observations have shown that CKD is associated with the high incidence of vitamin D deficiency. ${ }^{23}$ A study performed in 2004 with limited number of patients with CKD also showed that vitamin D insufficiency and deficiency were prevalent among patients with CKD, affecting 
$86 \%$ of the patients, and that the functional meaning of this finding is yet to be determined. ${ }^{1}$ In another analysis involving 76 Japanese patients with CKD, serum levels of $25(\mathrm{OH}) \mathrm{D}$ were associated with hypoalbuminemia, diabetes mellitus and serum phosphorus, but no correlation was found between serum levels of $25(\mathrm{OH}) \mathrm{D}$ and creatinine clearance of the patients. ${ }^{2}$ In these studies, $25(\mathrm{OH})$ $\mathrm{D}$ insufficiency and deficiency have also been associated with the presence of hyperparathyroidism during CKD, which leads to the evaluation of the levels of this vitamin in patients with CKD and hyperparathyroidism; if the value of $25(\mathrm{OH}) \mathrm{D}$ is lower than $30 \mathrm{ng} / \mathrm{mL}$, it is replaced.

Reasons for the high frequency of vitamin $\mathrm{D}$ deficiency in patients with CKD are not clear, although it has been described that renal dysfunction is a risk factor for vitamin D deficiency. ${ }^{24,25}$ Likewise, it is a known fact that the presence of nephrotic proteinuria is associated with vitamin D deficiency, possibly due to the urinary loss of vitamin D bound to its plasma carrier protein. ${ }^{26}$ As to the patients analyzed in this study, those who had the nephrotic syndrome presented serum levels of $25(\mathrm{OH}) \mathrm{D} \leq 30 \mathrm{ng} / \mathrm{mL}$. However, this factor should not be the only one, since many patients who did not have nephrotic proteinuria also presented with vitamin D deficiency. ${ }^{24}$ However, it is important to observe that the high frequency of vitamin D deficiency in our sample of patients with CKD $(73.6 \%)$ is not different from that recently demonstrated in healthy people living in São Paulo, in which $77.4 \%$ of the people presented serum levels of $25(\mathrm{OH}) \mathrm{D}<30 \mathrm{ng} / \mathrm{mL} .^{13}$

The consequences of vitamin D deficiency in patients with CKD are not established yet. This item is especially important due to the observation that administering active vitamin $\mathrm{D}$ in patients with dialytic CKD was associated with better survival rates, when compared to patients who did not use any vitamin $\mathrm{D}$ analogues. ${ }^{27,28}$ An analysis with 444 patients followed-up for about 9.4 years $-51.1 \%$ of mortality - showed that reduced levels of $25(\mathrm{OH}) \mathrm{D}$ were associated with mortality due to all causes and cardiovascular motives. $^{29}$

Therapy with ergocalciferol or colecalciferol in patients with CKD with $25(\mathrm{OH}) \mathrm{D}$ deficiency has been little described in literature, thus showing it is associated with high serum levels of this vitamin for most patients, and with the reduction of PTH levels among those who respond to treatment. ${ }^{26-28,30-32}$ However, the possible advantages of this supplementation are yet to be defined. Evidence shows that pleitropic effects of vitamin $\mathrm{D}$ go beyond bone and mineral metabolism and the activity of parathyroid glands, thus being possibly related to other potential areas of CKD. It has been demonstrated that vitamin $\mathrm{D}$ supplementation has an antiproteinuric effect, ${ }^{33}$ to regulate the reninangiotensin-aldosterone ${ }^{34}$, to reduce histological changes found in glomerulosclerosis, ${ }^{35}$, and, finally, to reduce CKD progression. ${ }^{4}$

To sum up even if our population with CKD is in a tropical environment, which leads to more exposure to the sun and, consequently, a higher production and serum levels of $25(\mathrm{OH}) \mathrm{D}$, our study showed that most analyzed patients had serum levels of $25(\mathrm{OH}) \mathrm{D}$ below recommended values, especially lower among women and in patients with larger abdominal circumference. These suboptimal serum levels of vitamin D can be related to the appearance of hyperparathyroidism.

\section{References}

1. Gonzales EA, Sachdeva A, Oliver DA, et al. Vitamin D insufficiency and deficiency in chronic kidney disease. A single center observational study. Am J Nephrol 2004;24:503-10.

2. Ishimura E, Nishizawa Y, Inaba M, et al. Serum levels of 1,25-dihydroxyvitamin D, 24-25-dihydroxyvitamin D, and 25-hydroxyvitamin D in nondialyzed patients with chronic renal failure. Kidney Int 1999;55:1019-27.

3. Ewers B, Gasbjerg G, Moelgaard C, et al. Vitamin D status in kidney transplant patients: need for intensified routine supplementation. Am J Clin Nutr 2008;87:431-7.

4. Al-Badr W, Martin KJ. Vitamin D and kidney diseases. Clin J Am Soc Nephrol 208;3:1555-60.

5. Del Valle E, Negri AL, Aguirre C, et al. Prevalence of $25(\mathrm{OH})$ vitamin D insufficiency and deficiency in chronic kidney disease stage 5 patients on haemodialysis. Hemodial Int 2007;11:315-21.

6. Lomonte C, Antonelli M, Vernaglione L, et al. Are low plasma levels of $25-(\mathrm{OH})$ vitamin $\mathrm{D}$ a major risk factor for hyperparathyroidism independent of calcitriol in renal transplant patients? J Nephrol 2005;18:96-101.

7. Heaf J, Tvedegaard E, Kanstrup IL, et al. Bone loss after renal transplantation: role of hyperparathyroidism, acidosis, cyclosporine, and systemic disease. Clin Transplant 2000;14:457-63.

8. Caravaca F, Fernandez MA, Cubero J, et al. Are plasma 1,25-0dihydroxyvitamin D3 concentrations appropriate after successful kidney transplantation? Nephrol Dial Transplant 1998;13(Suppl):S91-3.

9. Cannata-Andia JB, Gomez Alonso C. Vitamin D deficiency: a neglected aspect of disturbed calcium metabolism in renal failure. Nephrol Dial Transplant 2002;17:1875-8.

10. Fournier A, Fardellone P, Achard JM, et al. Importance of vitamin D repletion in uremia. Nephrol Dial Transplant 1999;14:819-23.

11. Holick MF. Vitamin D deficiency. N Engl J Med 2007;357:266. 
12. Cuppari L, Carvalho AB, Draibe SA. Vitamin D status of chronic kidney disease in patients living in a sunny country. J Ren Nutr 2008;18:408-14.

13. Unger M. [dissertation]. São Paulo: Faculdade de Medicina da Universidade de São Paulo; 2009.

14. Levey AS, Eckardt KU, Tsukamoto Y, et al. Definition and classification of chronic kidney disease: a position statement from kidney disease: Improving Global Outcomes (KDIGO). Kidney Int 2005;67:2089-100.

15. Sociedade Brasileira de Nefrologia - Diretrizes de Condução da Doença Renal Crônica. J Bras Nefrol 2004;26(Suppl):2-98.

16. Cockcroft DW, Gault MH. Prediction of creatinine clearance from serum creatinine. Nephron 1976;16:31-41.

17. Payne RB, Little AJ, Williams RB, et al. Interpretation of serum calcium levels in patients with abnormal serum proteins. BMJ 1973;4:643-46.

18. Kidney Disease: Improving Global Outcomes (KDIGO) CKD-MBD Work Group. KDIGO clinical practice guideline for the diagnosis, evaluation, prevention, and treatment of Chronic Kidney Disease-Mineral and Bone Disorder (CKD-MBD). Kidney Int Suppl 2009;113(Suppl):S1-130.

19. Chonchol M, Scragg R. 25-hydroxyvitamin D, insulin resistance, and kidney function in the Third National Health and Nutritional Examination Survey. Kidney Int 2007;71:134-9.

20. Linhares MF, Jones DA, Round JM, et al. Effect of nutrition on vitamin $\mathrm{D}$ status: studies on healthy and poorly nourished Brazilian children. Am J Clin Nutr 1984;39:625-30.

21. Saraiva GL, Lazaretti-Castro M, Cendoroglo MS, et al. Influence of ultraviolet radiation on the production of 25 -hydroxyvitamin $\mathrm{D}$ in the elderly population in the city of São Paulo (23034' S), Brazil. Osteoporos Int 2005;16:1649-54.

22. Peters BSE, Santos LC, Fisberg M, et al. Prevalence of vitamin D insufficiency in Brazilian adolescents. Ann Nutr Metab 2009;54:15-21.

23. LaClair RE, Hellman RN, Karp SL, et al. Prevalence of calcidiol deficiency in CKD: A cross-sectional study across latitudes in the United States. Am J Kidney Dis 2005;45:1026-33.
24. Reichel H, Deibert B, Schimidt-Gayk H, et al. Calcium metabolism in early chronic renal failure: Impilications for the pathogenesis of hyperparathyroidism. Nephrol Dial Transplant 1991;6:162-9.

25. Thomas MK, Lloyd-Jones DM, Thadhani RI, et al. Hypovitaminosis D in medical inpatients. N Engl J Med 1998;338:777-83.

26. Saha H. Calcium and vitamin D homeostasis in patients with heavy proteinuria. Clin Nephrol 1994;41:290-6.

27. Teng M, Wolf M, Ofsthun MN, et al. Activated injectable vitamin D and haemodialysis survival: a historical cohort study. J Am Soc Nephrol 2005;16:1115-25.

28. London GM, Guerin AP, Verbeke FH, et al. Mineral metabolism and arterial functions in end-stage renal disease: potential role of 25-hydroxyvitamin D deficiency. J Am Soc Nephrol 2006;18:613-20.

29. Pilz S, Tomaschitz A, Friedl C, et al. Vitamin D status and mortality in chronic kidney disease. Nephrol Dial Transplant 2011;26:3603-9

30. Al-Aly Z, Qazi RA, Gonzalez EA, et al. Changes in serum 25-hydroxyvitamin D and plasma intact PTH levels following treatment with ergocalciferol in patients with CKD. Am J Kidney Dis 2007;50:59-68.

31. Chandra P, Binongo JN, Ziegler TR, et al. Cholecalciferol (vitamin D3) therapy and vitamin D insufficiency in patients with chronic kidney disease: a randomized controlled pilot study. Endocr Pract 2008;14:10-7.

32. Zisman AL, Hristova M, Ho LT, et al. Impact of ergocalciferol treatment of vitamin D deficiency on serum parathyroid hormone concentrations in chronic kidney disease. Am J Nephrol 2007;27:36-43.

33. Agarwal R, Acharya M, Tian J, et al. Antiproteinuric effect of oral paricalcitol in chronic kidney disease. Kidney Int 2005;68:2823-8.

34. Li YC, Qiao G, Uskokovic M, et al. Vitamin D: a negative endocrine regulator of the reninangiotensin system and blood pressure. J Steroid Biochem Mol Biol 2004;89-90:387-92.

35. Kuhlmann A, Haas CS, Gross ML, et al. 1,25Dihydroxyvitamin D3 decreases podocyte loss and podocyte hypertrophy in the subtotally nephrectomized rat. Am J Physiol Renal Physiol 2004;286:F526-33. 